\title{
THE ENDOGENOUS CONCENTRATION OF ESTRADIOL AND ESTRONE IN NORMAL HUMAN POSTMENOPAUSAL ENDOMETRIUM
}

\author{
C. Vermeulen-Meiners $\dagger^{*}$, L. J. Benedex Jaszmann§̧, A. A. Haspels $\dagger$, J. Poortman $\ddagger$ \\ and J. H. H. THIJSSEN \\ tDepartment of Obstetrics and Gynecology, $\ddagger$ Department of Endocrinology, Academic Hospital, State \\ Iniversity of Utrecht, 101 Catharijnesingel, 3511 GV Utrecht, and §Department of Ohstetrics and \\ Gynecology, Regional Protestant Hospital Bennekom, The Netherlands
}

(Received 16 Fehruary 1984)

\begin{abstract}
Summary - The endogenous estrone $\left(E_{1}\right)$ and estradiol $\left(E_{2}\right)$ levels (pg/g tissue) were measured in 54 postmenopausal, atrophic endometria and compared with the $E_{1}$ and $E_{2}$ levels in plasma $(\mathrm{pg} / \mathrm{ml})$. The results from the tissue levels of both steroids showed large variations and there was no significant correlation with their plasma levels. The mean $E_{2}$ concentration in tissue was $420 \mathrm{pg} / \mathrm{g}, 50$ times higher than in plasma and the $E_{1}$ concentration of $270 \mathrm{pg} / \mathrm{g}$ was 9 times higher. The $E_{2} / E_{1}$ ratio in tissue of 1.6 , was higher than the corresponding $E_{2} / E_{1}$ ratio in plasma, being 0.3 . We conclude that normal postmenopausal atrophic endometria contain relatively high concentrations of estradiol and somewhat lower estrone levels. These tissue levels do not lead to histological effects.
\end{abstract}

\section{INTRODUCTION}

Epidemiological studies have identified a number of risk factors for endometrial cancer. Several of these factors are clearly related to the endogenous production of estrogens; in addition the use of exogenous estrogens in postmenopausal women is associated with an increased risk for endometrial cancer [1-4].

Obesity, considered to be the most important risk factor for endometrial pathology, is thought to act through its contribution to the peripheral conversion of androstenedione to estrone [5-6]. Especially in the postmenopause, the resulting continuous exposure of target tissues to the unopposed action of estrogens may be a causal factor in the development of endometrial cancer [7-9].

However, recent studies have shown that the production rate and the peripheral blood levels of estrone $\left(\mathrm{E}_{1}\right)$ and estradiol $\left(\mathrm{E}_{2}\right)$ are very similar in patients with this cancer, as compared to controls matched for body weight [10-12].

Although the predominant circulating estrogen in postmenopausal women is estrone, Tseng and Gurpide did show that the estrogen tightly bound to the nuclei of superfused human endometrium was not estrone but estradiol [13].

In a previous in vivo study we have shown that after a constant infusion of labelled $E_{l}$ for $12 \mathrm{~h}$ to postmenopausal women, there is a higher $E_{2} / E_{1}$ ratio in endometrial tissue as compared with peripheral plasma. In the cell nucleus only $E_{2}$ was accumulated even after an infusion of $E_{1}$ [14-15].

We therefore considered the possibility that tissue

*To whom correspondence should be addressed. levels of estrogens may be different from the plasma levels. As far as we know no data are available about endogenous $E_{1}$ and $E_{2}$ values in postmenopausal endometrium.

Therefore a study was initiated to measure tissue estrogens in normal postmenopausal endometrium.

\section{MATERIALS AND METHODS}

\section{Patients}

Normal atrophic endometrial tissue was obtained from fifty-four women, aged 47-76 years, who had their last menstrual period at least 1 year before. Years since menopause (Y.M.P.) varied between $1-30 \mathrm{yr}$, the range of bodyweight between $45-100 \mathrm{~kg}$. To quantitate overweight for each patient the Quetelet index was calculated, as bodyweight (in kilograms) divided by the square of height (in meters). The percent ideal bodyweight was calculated from the ideal weight, obtained from the Metropolitan Life Insurance Company tables. The data are given in Table 1. None of the participating patients had ever taken exogenous estrogens.

\section{Tissue}

Normal human atrophic postmenopausal endometrium was obtained at hysterectomy performed on the indication of myomata uteri or prolapsus uteri, or at a diagnostic curettage for postmenopausal bleeding. Operations were performed under general anaesthesia using standard procedures. Immediately after abdominal or vaginal hysterectomy the endometrium was scraped from the uterine cavity with a curette. The uterus and remaining endometrium was subjected to routine histological examination. Endo- 
Table 1. Plasma levels, years since menopause and weight

\begin{tabular}{lllcc}
\hline & $N$ & \multicolumn{2}{c}{ Mean Value \pm SD } & Range \\
\hline $\mathrm{E}_{1}$ & 38 & $30.9 \mathrm{pg} / \mathrm{ml}$ & 16.9 & $1-69$ \\
$\mathrm{E}_{2}$ & 38 & 15.5 & 23.9 & $1-117$ \\
Y.M.P. & 52 & $9.5 \mathrm{yr}$ & 8 & $1-30$ \\
& 38 & 10.9 & 9.2 & $1-30$ \\
Body weight & 53 & $70.9 \mathrm{~kg}$ & 11.4 & $45-100$ \\
& 38 & 70.7 & 12 & $45-100$ \\
Quetelet index & 53 & 26.8 & 4.2 & $18.3-37.6$ \\
& 38 & 27.0 & 4.4 & $18.3-37.6$ \\
\% Ideal weight & 53 & 129.7 & 20.3 & $89-183.5$ \\
& 38 & 130.9 & 21.6 & $89-183.5$ \\
\hline
\end{tabular}

Plasma estrone and estradiol, years since menopause (Y.M.P.), body weight, Quetelet index and \% ideal weight in a group of healthy postmenopausal women.

metrial tissue obtained at curettage was divided into two portions, one for steroid determinations, the other part for histological examination. The endometrial tissues for our study were stored at $-70^{\circ} \mathrm{C}$ until analysis.

In earlier experiments [15] histological examination of samples obtained in this way, revealed that, tissues referred to as endometrium are contaminated with about $15 \%$ myometrium. The amount of endometrial tissue ranged between 0.01 and $0.28 \mathrm{~g}$ per patient. In this study only tissues were used with the histopathological diagnosis of atrophic endometrium.

\section{Plasma}

Heparinized venous blood samples were taken from thirty-nine patients just before anaesthesia to determine endogenous levels of $E_{1}$ and $E_{2}$. After centrifugation to separate cells and plasma, the plasma was stored at $-20^{\circ} \mathrm{C}$ until analysis.

\section{Plasma estrogens}

Plasma $E_{2}$ and $E_{1}$ were measured by radioimmunoassays, using highly specific antisera raised in rabbits against their 6-carboxymethyloxime-derivates coupled to bovine serum albumin. After double extraction of the steroids from plasma with freshly distilled ether, the extracts were purified by column chromatography on Sephadex-LH-20 and analysed. $E_{2}$ and $E_{1}$ were eluted with toluene-methanol (92:8, $\mathrm{v} / \mathrm{v}$ ) and collected in separate fractions. Details of these assays have been described earlier [16].

\section{Tissue estrogens}

In postmenopausal atrophic endometria estrone and estradiol were measured with a method according to that described by van Landeghem et al. [17]. In brief the following method was used: the frozen tissue was chilled in liquid nitrogen at $-196^{\circ} \mathrm{C}$ and subsequently pulverized with a Micro-Dismembrator (Braun, Melsungen, W. Germany). After pulverization the powder obtained was homogenized in $1.8 \mathrm{ml}$ phosfate-buffer and $\left[{ }^{3} \mathrm{H}\right] \mathrm{E}_{1}$ and $\left[{ }^{3} \mathrm{H}\right] \mathrm{E}_{2}$ were added to enable correction for recovery. The extraction was done twice with ethanol-acetone $(1: 1, \mathrm{v} / \mathrm{v})$, the first time with $10 \mathrm{ml}$ and the second time with $5 \mathrm{ml}$, both times followed by centrifugation $\left(10^{\prime}\right.$, $2,500 \mathrm{~g})$. The pellet obtained was used to measure
DNA-content according to Burton [18]. The combined supernatants were concentrated to $1.5 \mathrm{ml}$ under a stream of nitrogen and $1 \mathrm{ml}$ of phosfate-buffer was added. Next extraction was done with $10 \mathrm{ml}$ of freshly distilled ether and the extract was taken to dryness at $45^{\circ} \mathrm{C}$ under a stream of nitrogen. The residue was subjected to chromatography on LH-20 column as for the plasma estrogens.

The following data were measured: DNA per pellet, $E_{1}$ and $E_{2}$ in the supernatant and the following data were calculated: ratio of $E_{1}$ and $E_{2}$ to DNA and concentration of $E_{1}$ and $E_{2}$ per gram tissue. From the 54 tissues, $3 \mathrm{DNA}$ concentrations are not available and from one portion the $E_{2}$ determination failed.

\section{Statistical analysis}

The data were analysed by means of Spearman's rank correlation test $\left(r_{\mathrm{s}}\right)$. Differences between two groups of data were tested by using Student $t$-test.

If estrone or estradiol in tissue were below the level of sensitivity of the assays, we have used $5 \mathrm{pg} / \mathrm{g}$ or $2 \mathrm{pg} / \mathrm{mg}$ DNA for our calculations. If these estrogens were not detectable in plasma $(<1 \mathrm{pg} / \mathrm{ml})$, we have used $1 \mathrm{pg} / \mathrm{ml}$ for our calculations.

The results on estrogen levels in tissue amounts of less than $0.05 \mathrm{~g}$, were equally distributed over the total range of observations and therefore these results have been included in our calculations.

The levels of $E_{1}$ and $E_{2}$ in tissue showed large variations, therefore in all figures results are expressed on a log-scale.

\section{RESULTS}

\section{Plasma estrogens}

Our findings on the plasma estrogen levels are given in Table 1, together with the data on body-

Table 2. Correlation coefficients between estrogen plasma levels and weight and years since menopause

\begin{tabular}{llc}
\hline & Estrone & Estradiol \\
\hline Body weight & $r_{\mathrm{s}}=+0.21$ & $r_{\mathrm{s}}+0.10$ \\
Quetelet index & $r_{\mathrm{s}}=+0.26$ & $r_{\mathrm{s}}=+0.15$ \\
$\%$ Ideal weight & $r_{\mathrm{s}}=+0.27^{*}$ & $r_{\mathrm{s}}=+0.13$ \\
Y.M.P. & $r_{\mathrm{s}}=+0.05$ & $r_{\mathrm{s}}=-0.09$ \\
\hline
\end{tabular}

Spearman's rank correlation coefficients of the patients characteristics and the measured $E_{1}$ and $E_{2}$ concentration in plasma $(n=38)$. ${ }^{*} P=0.1$, all other $P$ values $>0.1$. 
Table 3. Estrogen tissue and plasma concentrations

\begin{tabular}{|c|c|c|c|c|c|c|c|c|c|}
\hline & $N$ & $\begin{array}{c}\text { Mean } \pm S D \\
\log \mathrm{pg} / \mathrm{g}\end{array}$ & $\begin{array}{c}\text { Mean } \\
\mathrm{pg} / \mathrm{g}\end{array}$ & $N$ & $\begin{array}{c}\text { Mean } \pm \text { SD } \\
\log \mathrm{pg} / \mathrm{mg} \mathrm{DNA}\end{array}$ & $\begin{array}{c}\text { Mean } \\
\mathrm{pg} / \mathrm{mg} \text { DNA }\end{array}$ & $N$ & $\begin{array}{c}\text { Mean } \pm \mathrm{SD} \\
\log \mathrm{pg} / \mathrm{ml}\end{array}$ & $\begin{array}{l}\text { Mean } \\
\mathrm{pg} / \mathrm{ml}\end{array}$ \\
\hline $\begin{array}{l}\mathbf{E}_{1} \\
\mathbf{E}_{2}\end{array}$ & $\begin{array}{l}54 \\
53\end{array}$ & $\begin{array}{l}2.43 \pm 0.92 \\
2.62 \pm 0.75\end{array}$ & $\begin{array}{l}270 \\
417\end{array}$ & $\begin{array}{l}51 \\
50\end{array}$ & $\begin{array}{l}2.06 \pm 0.93 \\
2.33 \pm 0.60\end{array}$ & $\begin{array}{l}115 \\
214\end{array}$ & $\begin{array}{l}39 \\
39\end{array}$ & $\begin{array}{l}1.43 \pm 0.31 \\
0.88 \pm 0.48\end{array}$ & $\begin{array}{r}26.9 \\
7.6\end{array}$ \\
\hline
\end{tabular}

The mean ( $\pm S D$ ) tissue concentrations of $E_{1}$ and $E_{2}$ expressed as pg per gram tissue or as pg per mg DNA, were calculated after $\log$ transformation. These data were converted back to untransformed mean-values and are also given in this table. For comparison the mean concentrations $\mathrm{ISD}$ of $\mathrm{E}_{1}$ and $\mathrm{E}_{2}$ in plasma were added.

weight, Quetelet index, \% ideal weight and years after menopause (Y.M.P.).

In view of the fact that we had only 39 plasma samples available and because from one of the patients the bodyweight was unknown, the calculations were done with the data from 38 patients. The data obtained in this group of 38 patients are shown separately in Table 1. The correlation coefficients between the parameters given in Table 1 are summarized in Table 2.

These data show that there are no significant correlation coefficients. The highest correlation coefficients are found between the $\mathrm{E}_{\mathrm{l}}$ level in plasma and either \% ideal weight as well as Quetelet index, resp. +0.27 and +0.26 . Also no correlation coefficients are found between the $E_{2}$ level in plasma and bodyweight, Quetelet index or \% ideal weight. No correlation was found for plasma levels of both estrogens and Y.M.P.

\section{Tissue estrogens}

The amount of DNA in the tissue ranged from 0.2 to $8.4 \mathrm{mg} / \mathrm{g}$, the mean value being $3.2 \mathrm{mg} / \mathrm{g} \pm 2.1$ (SD). The levels of $E_{1}$ and $E_{2}$ in tissue showed large

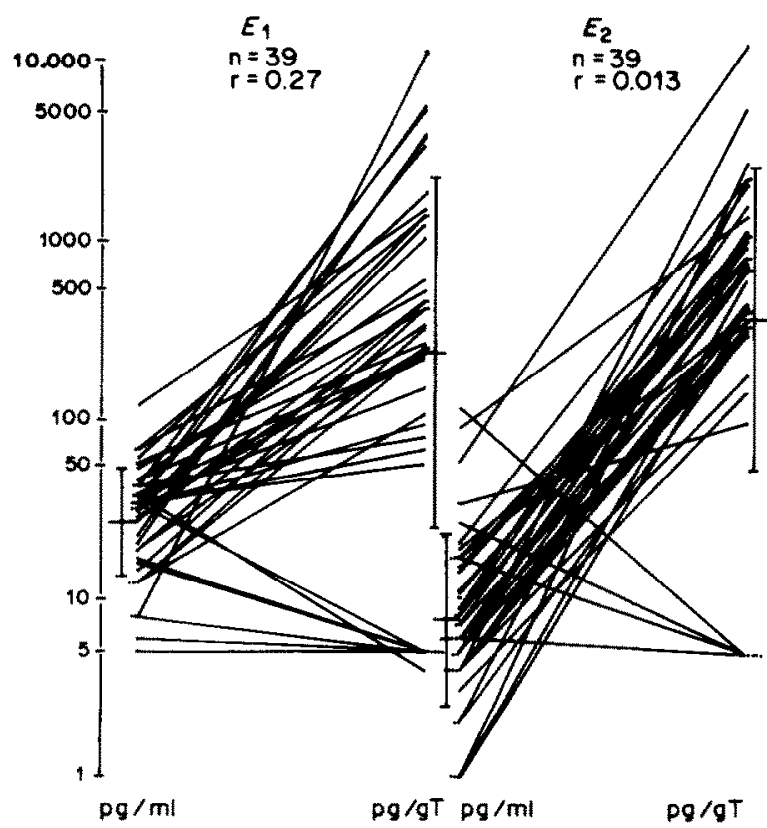

Fig. 1. The tissue $E_{1}$ and $E_{2}$ levels (in $\mathrm{pg} / \mathrm{gT}$ ) in relation to their plasma levels (in $\mathrm{pg} / \mathrm{ml}$ ) for each $(n=39)$ individual separately. The mean values $( \pm S D)$ for both variables are indicated by a vertical line at the left and right side in the figure. variations. The tissue level for $E_{1}$ ranged from $5-7,784 \mathrm{pg} / \mathrm{mg}$ DNA and from 5-11,479 pg/g tissue. The tissue level for $E_{2}$ ranged from $5-3,649 \mathrm{pg} / \mathrm{mg}$ DNA and from $5-12,670 \mathrm{pg} / \mathrm{g}$ tissue. Because of these large variations the calculations were done after log-transformation. The mean concentrations and standard deviations, calculated after logtransformation for $E_{1}$ and $E_{2}$ in endometrium and in plasma are given in Table 3 . The calculated meanvalues on log-basis, were converted back to untransformed mean-values to reduce the influence of extreme data, and also given in Table 3. The mean $\mathrm{E}_{\mathrm{t}}$ concentration in all the available tissue was calculated at $270 \mathrm{pg} / \mathrm{g}$ tissue and $115 \mathrm{pg} / \mathrm{mg}$ DNA, for $\mathrm{E}_{2}$ at $417 \mathrm{pg} / \mathrm{g}$ tissue and $214 \mathrm{pg} / \mathrm{mg}$ DNA. The estrogen

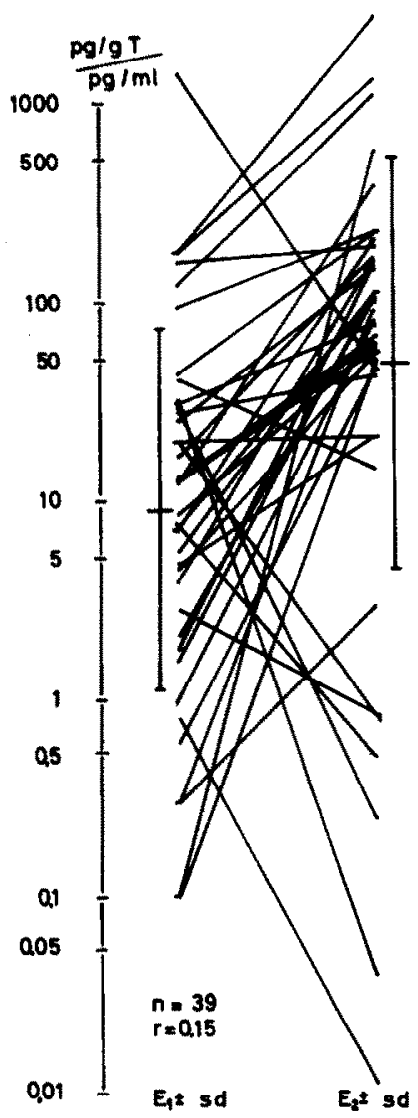

Fig. 2. The ratios between the tissue concentration (in $\mathrm{pg} / \mathrm{gT}$ ) and the plasma concentration (in $\mathrm{pg} / \mathrm{ml}$ ) of $E_{1}$ and $\mathrm{E}_{2}$. The data of the same subject are connected with a line. At the left and the right side the mean ratio $( \pm S D)$ is indicated by a vertical line. 
levels in tissue and plasma from all subjects for whom we had both data $(n=39)$ are shown in Fig. 1. For these 39 subjects the mean $E_{1}$ and $E_{2}$ concentration in tissue was resp. 240 and $372 \mathrm{pg} / \mathrm{g}$ tissue and is serum resp. 26.9 and $7.6 \mathrm{pg} / \mathrm{ml}$.

We found considerable variations in the tissue/plasma ratio (expressed as $\mathrm{pg} / \mathrm{g}$ and $\mathrm{pg} / \mathrm{ml}$, resp.) for both $E_{1}$ and $E_{2}$. Six subjects had lower tissue levels for $E_{1}$ as compared with plasma level and for $E_{2}$ five subjects had lower tissue levels. All other levels for estrogens in tissue were much higher than in plasma. There was no significant correlation between individual plasma and tissue levels of $E_{1}$ and $E_{2}$ (Fig. 1). Figure 2 shows the ratio between the tissue concentration in $\mathrm{pg} / \mathrm{g}$ and the plasma concentration in $\mathrm{pg} / \mathrm{ml}$ for $E_{1}$ and $E_{2}$. Data of the same subject are connected with a line. The mean tissue/plasma ratio for $E_{2}$ was significantly higher than for $E_{1}$ resp. $50.1 \pm 11$ (SD) and $9.1 \pm 8.1(P<0,001)$. The mean ratio's and SD are also indicated in Fig. 2. Eight out of the 39 subjects had a higher tissue/plasma ratio for $E_{1}$ than for $E_{2}$. The ratio for both estrogens are not correlated, $r_{\mathrm{s}}=0.15(P>0.1)$.

Comparison of the $E_{2} / E_{1}$ ratio in plasma (in $\mathrm{pg} / \mathrm{ml}$ ) and in tissue (in pg/g T), as depicted in Fig. 3, showed that there is a higher ratio in tissue (mean 1.6) than in plasma (mean 0.3).

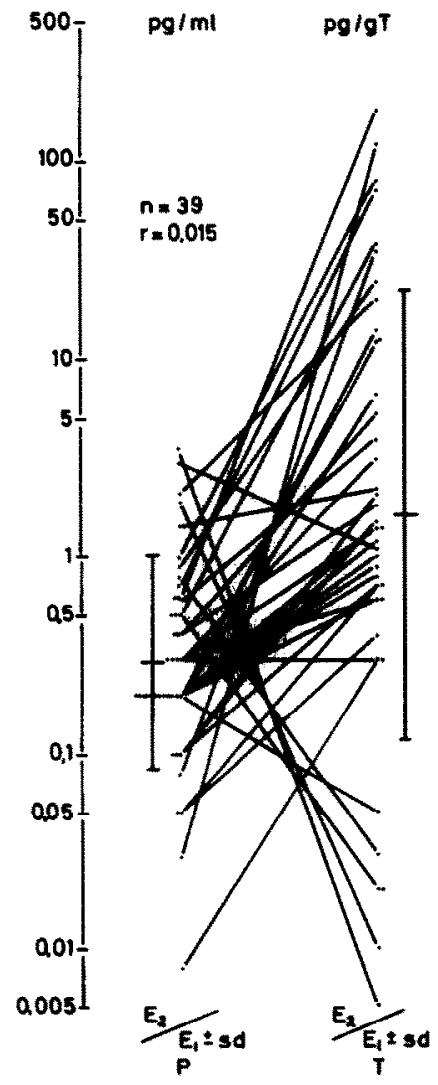

Fig. 3. The $\mathrm{E}_{2} / \mathrm{E}_{1}$-ratios in plasma (in $\mathrm{pg} / \mathrm{ml}$ ) as compared to the ratios in postmenopausal endometrial tissue (in $\mathrm{pg} / \mathrm{gT}$ ). At the left and the right side the mean ratio ( $\pm \mathrm{SD}$ ) is indicated by a vertical line.
From these data it is justified to conclude that postmenopausal atrophic endometrium contains more $E_{2}$ than $E_{1}$. Even when the plasma-level of $E_{2}$ is lower than for $E_{1}$, the tissue is able to build up a higher gradient for $E_{2}$ than for $E_{1}$.

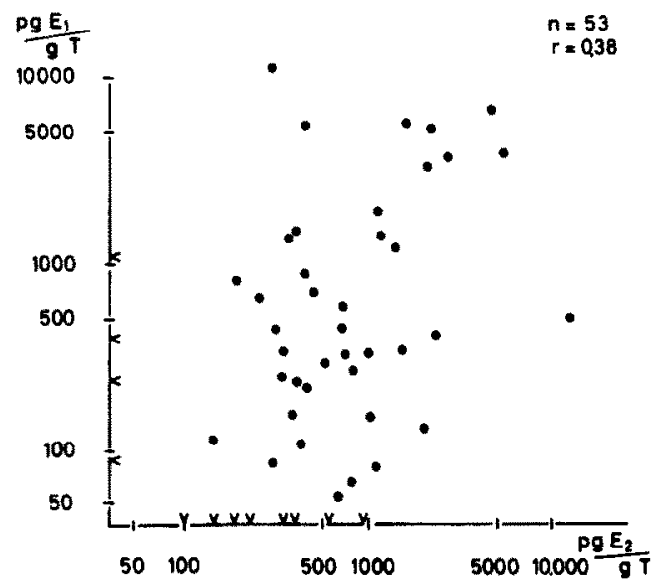

Fig. 4. The tissue $E_{1}$ levels (in $\mathrm{pg} / \mathrm{gT}$ ) plotted against the tissue $E_{2}$ levels (in $\mathrm{pg} / \mathrm{gT}$ ) for 53 patients. The symbol $<$ or $v$ at the $y$-axis and the $x$-axis indicates a value below the sensitivity of the assay used.
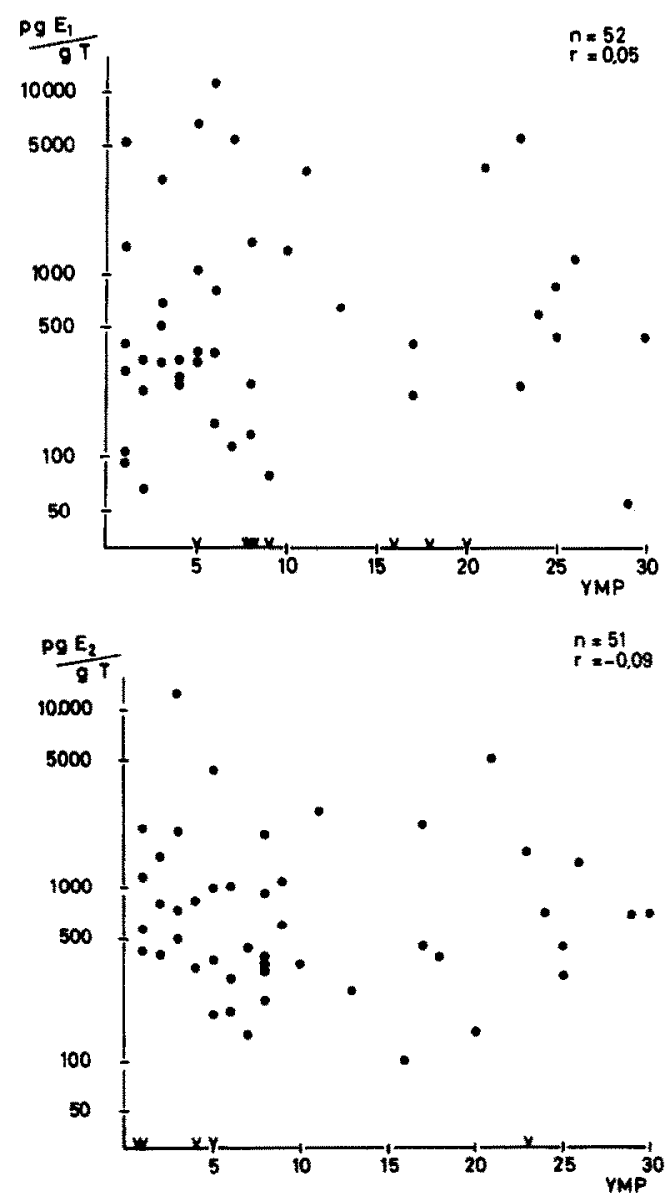

Fig. $5 \mathrm{a}$ and $\mathrm{b}$. Years since menopause (Y.M.P.) in relation with the tissue levels for $E_{1}$ and $E_{2}$ (in $\mathrm{pg} / \mathrm{gT}$ ); resp. The symbol $\vee$ at the $x$-axis indicates a value below the sensitivity of the assay used. 
In Fig. 4 the tissue $E_{1}$ levels were plotted against the tissue $E_{2}$ levels (both in $\mathrm{pg} / \mathrm{g}$ tissue) for 53 subjects. With an increasing $E_{1}$ tissue level we see an increasing $\mathrm{E}_{2}$ tissue level. $\left(r_{\mathrm{s}}=0.38, P<0.01\right)$. The Spearman's rank correlation coefficient between tissue level of $E_{1}$ ( $\mathrm{pg} / \mathrm{mg}$ DNA) against $E_{2}$ (in $\mathrm{pg} / \mathrm{mg}$ DNA) is $0.32(n=50, P<0.05)$. (Data not shown).

In Fig. $5 \mathrm{a}$ and $\mathrm{b}$ the years since menopause are plotted against the tissue $E_{1}$ and $E_{2}$ level ( $\mathrm{pg} / \mathrm{g}$ tissue), resp. There is no obvious fall in tissue $E_{1}$ or $E_{2}$ level with time elapsed since menopause.

\section{DISCUSSION}

In this study we investigated the levels of $E_{1}$ and $E_{2}$ in atrophic endometrial tissue from postmenopausal women in comparison with the corresponding plasma levels.

In our group of normal women, the mean $E_{1}$ level of $33.2 \mathrm{pg} / \mathrm{ml}(n=39)$ in plasma is slightly higher than that reported by Poortman et al. $(24.2 \mathrm{pg} / \mathrm{ml})$ [19]. Also our mean $E_{2}$ level of $15.1 \mathrm{pg} / \mathrm{ml}$ is somewhat higher. Our data are comparable to those reported by Judd et al. [10].

We found no significant correlation between estrogen levels in plasma and weight or Quetelet index or $\%$ ideal weight, in contrast to the findings published by Poortman and Judd. Their correlations were not very strong and therefore relatively small differences in the estrogen estimations at these very low levels can lead to loss of correlation between bodyweight and estrogen levels. On the other hand also Klinga et al. [20], were unable to find a correlation between $E_{1}$ levels and overweight and found only a weak correlation coefficient with weight $(r=0.31)$. In agreement with Poortman and Judd we did not find a correlation between plasma estrogens and years after the menopause.

In a recent study [14-15] the estrogen uptake by target tissues was studied in postmenopausal women after a long term $(12 \mathrm{~h})$ infusion of tritium-labelled estrogens.

A large gradient between tissue and plasma levels for endometrium, myometrium and vagina was found, the gradient being higher for $E_{2}$ and $E_{3}$ than for $E_{1}$ in all three tissues.

Estrogens are thought to be involved in endometrial disorders and they can exert their biological effect only after entrance into the cell. Therefore we wanted to measure these hormones at the tissue level. To our knowledge this is the first study in which quantitative data are given on endogenous estrogens in postmenopausal endometria, no comparable data are available.

The levels for $E_{1}$ and $E_{2}$ in the atrophic endometrial tissues showed a very large range and the tissue levels were much higher than the corresponding plasma levels. There was no significant correlation between plasma and tissue $E_{1}$ or $E_{2}$ levels. As we found no correlation between estrogen plasma levels and
Y.M.P., in addition we also could not find a correlation between estrogen tissue levels and Y.M.P.

The mean $E_{2}$ level in tissue was higher than for $E_{1}$, a slight but significant correlation $\left(r_{\mathrm{s}}=0.38, N=53\right)$ was found between these levels. This correlation is in accordance with the results of Wiegerinck et al. [15] who postulated an intracellular conversion of $E_{2}$ to $E_{1}$ in endometria of postmenopausal women.

As the $E_{2}$ level in serum is lower than for $E_{1}$, the tissue/plasma ratio of $E_{2}$ is higher than the ratio for $E_{1}$. Our mean ratio's were 50 and 9.1 resp. Wiegerinck et al., found an approx 30 times higher $E_{2}$ concentration in endometrium than in plasma and the corresponding $E_{1}$ tissue to plasma ratio was 7 for postmenopausal women using a different experimental approach [15].

Therefore, the accumulation of $E_{2}$ in atrophic endometria was a consistent finding. The differences in gradient between our results and those of others can possibly be attributed to different experimental approaches. The higher $E_{2}$ concentration in the cell can be explained by the longer intracellular and nuclear accumulation after uptake. The contribution of local endometrial aromatisation, as observed by Tseng [21], is as yet unclear.

Although the cells were clearly very active in building up a large gradient to plasma of mainly estradiol, histologically the endometrial tissues were classified as atrophic. So the high intracellular concentrations of these estrogens had no histological effect. It must be kept in mind that our determinations were done on total tissue, because too little tissue per patient was available to allow determinations in the subcellular fractions.

In view of the results of Wiegerinck et al. [15] in subcellular distribution of the infused estradiol it is to be expected that also the endogenous estradiol is mainly present in the nuclear compartment of the cells. Therefore it is difficult to understand why the high $\mathrm{E}_{2}$ concentrations in the presence of estradiol receptors do not lead to histological effects. It seems that either still higher $\mathrm{E}_{2}$ concentrations are necessary to elicit effects, at least in the absence of progesterone or another possibility might be the necessity of unknown factors for histological results.

In conclusion: normal postmenopausal atrophic endometria contain relatively high concentrations of estradiol and somewhat lower estrone levels. These tissue levels do not lead to histologically demonstrable effects.

Acknowledgements - The authors gratefully acknowledge the excellent technical assistance of Miss L. A. van Bruchem and the assistance of the pathologist F. B. Bronkhorst. We thank Miss H. G. F. Roodvoets for typing the manuscript. This study was supported by a grant from the Dutch Prevention Fund (Preventiefonds).

\section{REFERENCES}

1. Wynder E. L., Escher G. C. and Mantel N.: An epidemiological investigation of cancer of the endometrium. Cancer 19 (1966) 489-520. 
2. Lucas W. E.: Causal relationship between endocrinemetabolic variables in patients with endometrial carcinoma. Obstet. Gynec. Survey 29 (1974) 507-528.

3. Gurpide E.: Hormones and gynecologic cancer. Cancer Suppl. 38 (1976) 503-508.

4. Knab D. R.: Estrogen and endometrial cancer. Obstet. Gynec. Survey 32 (1977) 267-281.

5. Edman C. D., Aiman E. J., Porter J. C. and MacDonald P. C.: Identification of the estrogen product of extraglandular aromatization of plasma androstenedione. Am. J. Obstet. Gynec. 130 (1978) 439-447.

6. MacDonald P. C., Rombaut R. P. and Sitteri P, K. Plasma precursors of estrogen. I. Extent of conversion of plasma $\Delta 4$-androstenedione to estrone in normal males and nonpregnant normal, castrate and adrenalectomized females. J. clin. Endocr. Metab. 27 (1967) $1103-1111$.

7. Gusberg S. B.: Current concepts in cancer. The changing nature of endometrial cancer. N. Engl. J. Med. 302 (1980) 729-731.

8. Ziel H. K.: Estrogen's role in endometrial cancer. Obstet. Gynec. 60 (1982) $509-515$.

9. The British Gynecological Cancer Group: Oestrogen replacement and endometrial cancer. The Lancet 1 (1981) $1359-1360$

10. Judd H. L., Davidson B. J., Frumar A. M., Shamonki I. M., Lagasse L. D. and Ballon S. C.: Serum androgens and estrogens in post-menopausal women with and without endometrial cancer. Am. J. Obstet. Gynec. 136 (1980) 859-866.

11. Judd H. L., Lucas W. E. and Yen S. S. C.: Serum $17 \beta$-estradiol and estrone levels in postmenopausal women with and without endometrial cancer. $J$. clin. Endocr. Metab. 43 (1976) 272-278.

12. MacDonald P. C., Edman C. D., Hemsell D. L., Porter J. C. and Siteri P. K.: Effect of obesity on conversion of plasma androstenedione to estrone in postmenopausal women with and without endometrial cancer. Am. J. Obstet. Gynec. 130 (1978) 448-455.
13. Tseng L. and Gurpide E.: Nuclear concentration of estradiol in superfused slices of human endometrium. Am. J. Obstet. Gynec. 114 (1972) 995-1001.

14. Thijssen J. H. H., Wiegerinck M. A. H. M., Mulder G and Poortman J.: On the biological activity of estrone in vivo. In Frontiers in Hormone Research (Edited by $L$. Lauritzen and P. A. Keep). Karger, Basel, Vol. V (1978) $220-229$.

15. Wiegerinck M. A. H. M., Poortman J., Donker T. H. and Thijssen J. H. H.: In vivo uptake and subcellular distribution of tritium-labeled estrogens in human endometrium, myometrium and vagina. $J$. clin. Endocr. Metab. 56 (1983) 76-86.

16. Landeghem A. A. J, van, Poortman J., Deshpande N., Martino L. Di., Targuini A., Thijssen J. H. H. and Schwarz F.: Plasma concentration gradient of steroid hormones across human mammary tumor in vivo. $J$. steroid Biochem. 14 (1981) 741-747.

17. Landeghem A. A. J. van, Poortman J., HelmondAgema A. and Thijssen J. H. H.: Measurement of endogenous subcellular concentration of steroids in tissue. J. steroid Biochem. 20 (1984) 639-644.

18. Burton $\mathrm{K}$.: A study of the conditions and mechanism of the diphenylamine reaction for the colorimetric estimation of deoxyribonucleic acid. Biochem. J. 62 (1956) 315-323.

19. Poortman J., Thijssen J. H. H. and Waard F. de: Plasma oestrone, oestradiol and androstenedione levels in postmenopausal women: relation to body weight and height. Maturitas 3 (1981) 65-71.

20. Klinga $K$, Holst Tvon and Runnebaum B.: Serum concentrations of FSH, oestradiol, oestrone and androstenedione in normal and obese women. Maturitas 4 (1982) 9-17.

21. Tseng L., Mazella J., Mann W. J. and Chumas J. Estrogen synthesis in normal and malignant human endometrium. J. clin. Endocr. Metab. 5 (1982) $1029-1031$. 